\title{
Take-away Thoughts: Reflecting on Four Case Studies
}

\author{
REBECCA CONARD
}

$\mathrm{N}$

ow that public history, both as professional practice and academic field, has generated an international network, the commensurate traffic of ideas quite naturally is leading to collaborative ventures to see what we can learn from one another, or learn together. The four case studies presented here are only a sampling of activities that fall under the broad heading of international, or transnational, collaboration. Nevertheless, this quartet helps to clarify the challenges involved in developing successful partnerships and sustaining them beyond one or two projects. Financial considerations and administrative systems loom large as challenges to sustainability, but the case studies also point to a commensurate need for an intellectual apparatus that can integrate collaborative ventures into the pedagogy of public history and provide a rationale for sustainability.

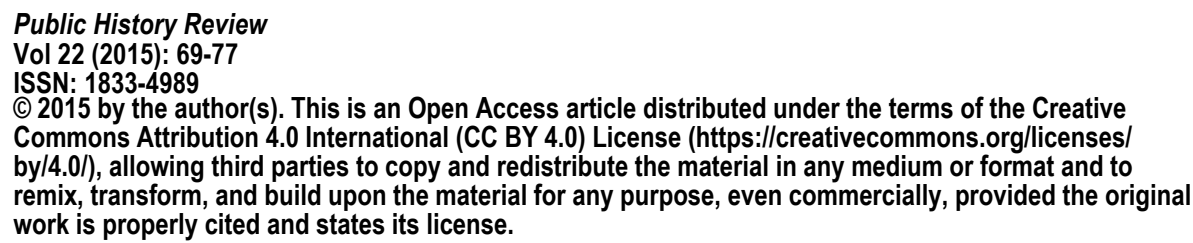


Each author, however, offers individual insights and suggestions based on his or her experience, and each study merits consideration before turning to the broader implications.

Richard Harker's incisive retrospective critique of the transnational collaboration between the Museum of History and Holocaust Education at Kennesaw State University in the United States and the Ben M'sik Community Museum in Casablanca, Morocco, provides a coda to the more descriptive coverage this collaboration received in The Public Historian (TPH) in 2012.' Together, Harker's assessment of the pedagogical values and the project leaders' roundtable in TPH convey a more complete sense of the logistical challenges to implementing transnational collaborative undertakings, only some of which can be facilitated by communications technology; the tremendous satisfaction that attends successful projects; the intangible benefits of cross-cultural learning; the need to consider, at the outset, the relative positions of institutional partners, in terms of professional development, financial resources, and the larger cultural milieu in which each institution exists; and the long-term financial realities that limit the sustainability of transnational partnerships. The 2012 roundtable highlights the first three aspects of the project, while Harker takes on the issue of power differentials forthrightly. Both frankly acknowledge the sustainability issues.

Harker begins his critique by noting that the central aim of the first grant-funded project, a comparative oral history project that engaged American and Moroccan undergraduate students in people-to-people research, was to break down cultural stereotypes and build trust.

Similarly, the second project, also grant-funded, sought to deepen crosscultural knowledge by engaging a new group of American and Moroccan undergraduate students in creating an online exhibit that incorporated oral histories conducted by the first group. To sharpen his focus on the power differentials that became obvious during the process of each undertaking, Harker draws on the concept of 'shared inquiry' as articulated by Katharine Corbett and Howard Miller, which, in turn, builds on Michael Frisch's concept of 'shared authority' and Donald Schön's related concepts of 'reflective practice' and 'reflection-in-action'. 'Shared authority', Corbett and Miller point out, keeps issues of agency 'at the forefront', while collaborators are reflexively 'monitoring and adjusting' their responses and 'behavior' - or reflecting in real time throughout the processes of 'shared inquiry.'

In the context of this methodological construct, Harker examines the inherent power imbalance between the two partners and two particular instances of conflict in the collaborative process. First, he points to 
specific imbalances in professional expertise, public history training and financial resources that opened the American team to charges of 'cultural imperialism'. He intimates that Moroccan critics were not able to exploit this charge because the Moroccan coordinator operated with enough autonomy, or cultural authority, that he could navigate the oral history project to a to successful outcome. Although the American facilitators certainly were sensitive to the power imbalance, and adjusted accordingly, one has to ask whether more collaboration in the planning phase might have resulted in additional project components to address specific imbalances before bringing students into the process. As a case in point, had there been more collaboration on the planning end, the American and Moroccan partners would have confronted early on the cultural differences over paying oral history narrators and thus avoided the conflict that ensued when the Moroccan team and their narrators jointly decided to use funds budgeted for paying narrators to purchase computers for a school. The second incident, resolving an 'impasse' that American and Moroccan students reached in deliberating the design elements of a logo for the online exhibit, underscores the subtleties of building trust. Making an 'executive decision' that placed the final design in the hands of an American graphic designer resolved the impasse expediently. However, even though all the students professed that the final design was a satisfactory compromise, the American coordinator was left with an uneasy feeling that the logo might ultimately be viewed a symbol of the power imbalance that marked the whole undertaking.

By focusing on the power differentials and examining two episodes that brought cultural differences into sharp relief, Harker teases out the methodological and pedagogical challenges of transnational collaboration. Ultimately, the long-term costs of creating sustainable collaborations may dwarf the intellectual challenges. However, when circumstances and funding make transnational collaboration feasible, Harker's critique suggests that public historians be more mindful of methodological issues and cultural differences in the planning phase rather than sorting things out on the fly once the effort is underway. Planning, of course, takes time, which is always in short supply when an application deadline is looming. But something as simple as involving all key partners in constructing the budget could at least flag issues that need further discussion before a project starts or that need time for discussion during a project. This might enhance the pedagogical value of transnational collaboration, especially grant-funded undertakings that are likely to be episodic rather than ongoing efforts. 
Karina Esposito raises the intriguing proposition of using the history and heritage of Americana, a town near Santa Barbara D'Oeste in San Paulo, Brazil, to open up a dialogue about the American Civil War (18611865) in a transnational context. Specifically, she sees the historicalcultural traditions of this South American enclave as an opportunity to engage students in a more honest discussion of US history by 'removing the barriers that sometimes generate an immediately defensive posture'. Americana and Santa Barbara D'Oeste form the cultural center of the Confederados, descendants of several thousand Confederates who, at war's end, fled to Brazil, some with their former slaves, rather than stay in the re-united states. Now, several generations later and intermarried with native Brazilians or other immigrant groups, the Confederados represent a culture group that, on the surface at least, is oddly familiar to Americans, yet strikingly different.

The most prominent display of culture occurs at an annual festival, Festa Confederada, where an increasingly diverse population of descendants gathers to perform white Southern culture - dress in hoop skirts and Confederate uniforms, square dance to fiddle music, eat fried chicken and banana pudding and fly the Confederate flag while singing the Brazilian national anthem. Accounts of the festival by American tourists tend to dwell on the seeming lack of racism, or even racial overtones, and it is this quality that Esposito seizes upon as framework for discussing (with US students) the history and commemoration of the Civil War in a transnational context in order to move beyond racially charged engagement in 'opposing viewpoints.' Unfortunately, although Esposito indicates that she uses such a cross-cultural approach in the classroom, she does not explain how she structures and guides discussion to arrive at a moment when students can begin to engage in open and honest dialogue about the comparative legacies of slavery in America, Brazil, and the Caribbean; institutionalized racism in the US and elsewhere; or the contemporary, international problem of human trafficking. The critical pedagogical piece remains elusive but tantalizing with possibilities. All too often classroom discussions of the Civil War and interpretations at Civil War historic sites are exercises in avoiding the elephant in the room, and we need creative frameworks that encourage more reflective thinking about the causes, consequences, and continuing relevancy of a transformative event that had international as well as national effects.

Elizabeth Catte takes cross-cultural research in a different direction by examining the public historical practices of another country. Reflecting critically on her experience working for Manx National Heritage $(\mathrm{MNH})$ on the Isle of Man, in a manner that resembles the 
participant observation method of qualitative research, Catte elucidates how she came to understand more clearly the power of cultural policy to shape national identity and social cohesion in this island nation. While noting that there are limits to what $\mathrm{MNH}$ can 'brand' as distinctive national heritage, Catte demonstrates that this statutory body nonetheless wields considerable authority in using history and heritage to shape Manx cultural identity. Among other things, it does this by controlling the narrative of national history, promoting public events that celebrate Viking and Celtic heritage, and reviving Manx Gaelic as a 'symbolic public language.' Catte notes that MNH draws its strength, in part, from a long history of Manx Celticism dating back to the latenineteenth century, which sought to separate Manx from the 'collective' British identity. But, she asserts, MNH's subtle 'construction' of Manx history and cultural identity through a state-controlled heritage delivery system also alienates many migrant workers and working-class natives.

Drawing on her training in public history in the United States, Catte points to comparisons she began to make while she was living on the Isle of Man. Among them, she observes that the Manx Museum emphasizes the island's role as a holding place for 'enemy aliens' during World War II and marginalizes its military contributions to winning both wars, a choice she and other critics attribute to $\mathrm{MNH}^{\prime}$ 's dedication to promoting Manx 'otherness'. While the US National Park Service interprets America's own shameful incarceration of Japanese-American citizens during World War II at Manzanar National Historic Site, she notes that associating the Isle of Man's wartime internment camps with the history of British oppression of minorities stands in stark contrast to the triumphal interpretations of both world wars that one finds more generally throughout the UK and US.

Catte's critique of the Isle of Man's heritage industry implicates public history institutions as central players in identity politics. But she stops short of examining the lessons for public history pedagogy. Her experience working with the Education Department of Manx National Heritage suggests that we might begin by expanding pubic history curricula to include comparative courses that examine, through transnational case studies such as hers, the role that public history institutions play in facilitating not only the teaching of history but also the transmission of national identity through curriculum-based public programming and interpretive materials.

Brittany Ghee presents another case study that is well suited for comparative analysis. Ghee admits at the outset that 'a bit of self reflection' after her internship with the National Museum of Ghana led 
her to a much deeper understanding of the museum's collections and interpretive 'rhetoric' in relation to 'the formation of national identity'. Her admission, and the more reflective museum evaluation that is the heart of her article, provides a sense of the pedagogical value of integrating transnational case studies into public history curricula. On one level, such case studies could examine differences in preservation, curatorial, or interpretive techniques, but moving to the level of institutional history creates a pathway for comparing the ways that museums in different countries use their collections to transmit cultural policy.

In her case study, Ghee discovered that the narrative confusion produced by the five different elements of the permanent exhibition, related only in the sense that all of them focused on Ghana's cultural diversity, made more sense once she understood the origins of the museum as an institution and key transition points in its history. Many of the museum's collections were donated by British collectors associated in one way or another with the operations of the British Empire in West Africa. Between the museum's creation in 1924 and 1957, when the Gold Coast became the independent country of Ghana, these artifacts were meant to cultivate respect for distinctive indigenous cultures, and thereby, British colonials hoped, foster harmonious relations among tribal chiefs and native leaders in order to maintain a system of indirect rule. When Kwame Nkrumah came to power in 1957 as Ghana's first president, he promoted pan-Africanism and solidarity among other new African nations in order to present a united front in international affairs. The National Museum's collections thus took on added value for promoting a cultural policy of 'unity through diversity'.

In reflection, Ghee realized that the 'unity through diversity rhetoric' was everywhere represented in the museum's permanent exhibition. What was perfectly intelligible to Ghanaian visitors without an interpretive apparatus needed explanation to outsiders like herself. She found that meaning by delving into the museum's own history. From this historical perspective, Ghee then was able to see the fifth element of the exhibition, which focuses on the Transatlantic slave trade, not as an odd juxtaposition to the cacophony of culture presented elsewhere but evidence of an evolving metanarrative. Initially preserved as examples of European architecture, the forts and castles that once served the slave trade are now interpreted in an international context as sites associated with the African diaspora, thus extending the unity through diversity message to include the descendants of once-enslaved Africans.

Reflecting on these four case studies, the first thing to note is that only one of the four addresses an actual collaborative venture. However, 
international or transnational collaborations will surely increase as the public history network expands globally. The Museums Connect grant program, a joint initiative of the US Department of State's Bureau of Educational and Cultural Affairs and the American Alliance of Museums, which funded the collaboration between Kennesaw State University's Museum of History and Holocaust Education and the Ben M'sik Community Museum in Casablanca, provides one source of funding for short-term collaborations. Museums Connect funding guidelines also provide a template of sorts inasmuch as the program encourages projects that fit its mission: 'to build global communities through cross-cultural exchanges while also supporting U.S. foreign policy goals, such as youth empowerment, environmental sustainability and disability rights awareness. ${ }^{\prime}{ }^{3}$ In the last three rounds (2013-2015), the Museums Connect program has funded twenty-seven collaborative projects; eight of them represent partnerships that use history or cultural heritage as a basis for cross-cultural exchange through people-to-people projects. Other types of grant programs encourage international collaboration between humanities scholars and research groups, such as the Netherlands Organization for Scientific Research (NOW), Humanities Division; the US National Endowment for the Humanities; and the new 'Uses of the Past' grant program organized by Humanities in the European Research Area and jointly funded by the European Commission and twenty-four national funding bodies in Europe and the UK.

Philanthropic sources of funding also will drive international collaborations, such as the ongoing joint conservation project between the Getty Conservation Institute in Los Angeles, funded by the J. Paul Getty Trust, and China's Dunhuang Academy to preserve and manage the ancient Magao Grottoes, a World Heritage Site in Gansu Province. The most important lesson learned over the years, according to three of the principals involved in this conservation project, is that 'collaborations must be relationship focused.' Elaborating on this point, they caution that:

Good relations and working practices take time to build and are established at the personal level, not at the signing of the agreement. In other words, a successful partnership is built up, not down.

Richard Harker's critique amplifies their observations and demonstrates that ventures undertaken with short-term funding, even when they are 
process- rather than product-focused, truncate the relationship-building process. This, in turn, exacerbates sustainability issues.

The Guantánamo Public Memory Project (GPMP) offers an alternative model for collaboration. ${ }^{\circ}$ Although this project is US-based, its aim is to use the history of Guantánamo naval station in Cuba to stimulate international dialogue on a divisive contemporary issue of global importance: the quasi-legal and secretive detaining of individuals deemed to be a threat to national security. Initiated in 2009 by the International Coalition of Sites of Conscience and managed by the Institute for the Study of Human Rights at Columbia University, the GPMP partners with many universities and organizations who 'collaborate' through a web interface that keeps track of a steadily growing number of separate projects. To date, partners have included the public history programs at Brown University, Indiana UniversityPurdue University at Indianapolis, New York University, University of California Riverside, and University of Massachusetts Amherst. The financial cost of sustaining the GPMP is borne by the individual partners, who design and develop projects - such as digital and physical exhibits, oral histories, online research resources, curriculum materials and public events - suited to their own resources and audiences.

The case studies of Karina Esposito, Elizabeth Catte and Brittany Ghee suggest a different approach to international collaboration: integrating cross-cultural studies of public history practice into public history curricula. The pedagogical value seems clear. Both Catte and Ghee note the extraordinary power that museums and historic sites have to create national identity. Ghee further observes that successful collaboration depends upon 'international discourses of public history'. Such discourse already takes place in conference settings, but at present, few universities offer comparative public history courses. While many public history educators surely incorporate comparative examples of public history practices in other countries into their courses, the internationalizing of public history opens a path to more rigorous transnational discourse. The major challenge comes in designing comparative courses that stimulate critical thinking in addition to expanding practical knowledge and skills. This would require in-depth case studies that have already been subjected to some level of analysis. A related concern would be devising strategies for incorporating actual cross-cultural dialogue so that learning is not filtered through one cultural perspective. Building international discourse into the curriculum provides, as Ghee notes, a platform for developing long-term initiatives that involve collaborative field projects. It should be noted that transnational collaboration is not exactly a new trend in public 
history pedagogy, as evidenced by the long-running summer program developed by Constance Shultz in 1990, which partnered the University of South Carolina Public History Program with Kiplin Hall, a historic site in North Yorkshire, England. Still, these four case studies point, each in its own way, to the more deeply humanistic value of transnational discourse in public history and the comparative study of public history practices worldwide.

None of the challenges to international collaboration, whether onthe-ground, people-to-people projects or partially processed case studies for indirect, reflective study, pose insurmountable problems. As William Willingham concluded, after reflecting on his own experience working with water resource historians in Holland to produce a retrospective study comparing Dutch and US water resource management practices, 'the contribution to historical scholarship that such international public history projects can produce and the opportunity to collaborate with and learn from international partners make any potential problems minor in comparison.'s But the contributions can be extended beyond scholarship and cross-cultural learning to include changes in public history pedagogy, which may lead to a more critical examination of the role that public history plays is shaping the cultural contours that divide as well as unite us.

\section{ENDNOTES}

${ }^{1}$ Catherine Lewis, Jennifer Dickey, Samir El Azhar, and Julia Brock, 'Exploring Identities: Public History in a Cross-Cultural Context', The Public Historian, vol 34, no 4, 2012, pp9-29.

${ }^{2}$ Katharine T. Corbett and Howard S. Miller, 'A Shared Inquiry into Shared Inquiry', The Public Historian, vol 28, no 1, 2006, pp17-8. See also Michael Frisch A Shared Authority: Essays on the Craft and Meaning of Oral History and Public History, SUNY Press, Albany, NY, 1990 and Donald Schön, The Reflective Practitioner: How Professionals Think in Action, Basic Books, New York, 1984.

${ }^{3}$ Museums Connect program statement, American Alliance of Museums website, http://www.aamus.org/resources/global-partnerships/museumsconnect, accessed 12 October 2015.

${ }^{4}$ Neville Agnew, Martha Demas, and Wang Xudong, 'The Enduring Collaboration of the Getty Conservation Institute and the Dunhuang Academy in Conservation and Management at the Buddhist Cave Temples of Dunhuang, China', The Public Historian, vol 34, no 3, 2012, pp7-20.

5 ibid, p19.

${ }^{6}$ See http://gitmomemory.org.

${ }^{7}$ Constance Shultz, comment from the audience, Working Group on 'Teaching Public History Through International Collaboration', National Council on Public History Conference, 15-18 April 2015.

${ }^{8}$ William Willingham, 'International collaboration and comparative research', blog post on Public History Commons, 22 June 2015, hosted by the National Council on Public History, www.ncph.org. 